\title{
Rol Belirsizliği ve Rol Çatışmasının İş Performansına Etkisinde İş Tatmininin Aracılık Rolü: Mersin İlinde Faaliyette Bulunan Özel Hastaneler Üzerine Bir Araştırma*
}

\section{The Mediating Role of Job Satisfaction within the Impact of Role Ambiguity and Role Conflict on Job Performance: A Research on Operating Private Hospitals in Mersin}

\author{
Onur Başar Özbozkurt, ${ }^{\text {*** }}$ Neslihan Özbozkurt ${ }^{\mathrm{b}}$ \\ ${ }^{a}$ Dr. Öğr. Üyesi, Çağ Üniversitesi, İktisadi ve İdari Bilimler Fakültesi, Uluslararası İlişkiler Bölümü, Mersin/Türkiye \\ ORCID:0000-0002-2325-2433
}

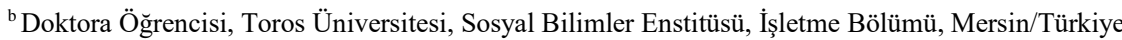
ORCID: 0000-0001-8143-7594

\section{MAKALE BİLGISII}

\section{Makale Geçmişi:}

Başvuru tarihi: 01 Şubat 2019

Düzeltme tarihi: 21 Nisan 2019

Kabul tarihi: 16 Mayıs 2019

\section{Anahtar Kelimeler: \\ Rol Belirsizliği \\ Rol Çatıșması \\ İş Performans \\ İş Tatmininin Aracılık Rolü}

\section{A R T I CLE INFO}

\section{Article history:}

Received 01 February 2019

Received in revised form 21 April 2019

Accepted 16 May 2019

\section{Keywords:}

Role Ambiguity

Rol Conflict

Job Performance

Mediating Role of Job Satisfaction
ÖZ

Rekabet ortamındaki işletmeler, her geçen gün hızla değişen ve gelişen bu rekabet yarışının gerisinde kalmamak için çalışan performansının artırılmasını arzu ederken; diğer taraftan çalışanlar, hiyerarşiden kaynaklanan rol belirsizliği ve rol çatışması ile karşılaşırlar. Çalışmanın temelini oluşturan özel sağlık sektöründe ise, birçok meslekten farklı olarak kendine özgü bir yapılanma ve görev tanımı bulunmaktadır. Bu bağlamda, araştırma için Mersin ilindeki özel hastanelerde 400 sağlık çalışanı üzerinde anket uygulaması gerçekleştirilmiş, özel sağlık sektörü çalışanlarının rol belirsizliği ve rol çatışmasının performanslarına etkisi ve iş tatmininin aracılık rolü araştırılmıştır. Analiz sonucunda, rol belirsizliği ve rol çatışmasının özel sağlık sektörü çalışanlarının performansı ile iş tatminini olumsuz yönde etkilediği ve iş tatmininin rol belirsizliği ve rol çatışması üzerinde aracılık rolü olup, çalışanların performansını olumlu yönde etkilediği görülmüştür.

\section{A B S T R A C T}

While rapidly changing and developing competition day by day, businesses in a competitive environment desire to increase the performance of employees to not stay behind the competition, employees may face with role ambiguity and role conflict arising from the hierarchy. The private healthcare sector which is the main subject of this study has a unique structuring and different job description from another sector. In this sense, the survey has been applied on 400 employees in private hospitals; Mersin and the effect of role ambiguity and role conflict on the performance of employees of healthcare sector and the mediating role of job satisfaction have been studied. It has been revealed that role ambiguity and role conflict have a negative effect on the performance and job satisfaction of employees of the private healthcare sector; at the same time, job satisfaction has a mediating role on role ambiguity and role conflict and positive effect on their performance as a result of the analysis.

\section{Giris}

Yoğun rekabet ortamında, işletmelerin önceden belirledikleri amaç ve hedefleri hayata geçirebilmek için başarılı olmaları ve varlıklarını sürdürebilmeleri önem arz etmektedir. Günümüz yönetim algıs1, yöneticilere,

çalışanların iş performansını ve tatminini artırma ve geliştirme bilincini aşılamaktadır. Sağlık sektöründe ise, işletmelerin en önemli sermayelerinin insan kaynağ görüşü faaliyet gösteren kurum ve yöneticiler tarafindan anlaşılmaya başlanmıștır (Çarıkçı ve Oksay, 2004: 160).

\footnotetext{
* Bu çalışma, ikinci yazarın, Toros Üniversitesi Sosyal Bilimler Enstitüsü İşletme Yönetimi Anabilim Dalı’nda gerçekleştirdiği “Sağlık Çalışanlarının Rol Belirsizliği ve Rol Çatışmasının İș Performansına Etkisi, İș Tatminin Aracılık Rolü: Mersin İli Özel Hastanelerinde Bir Çalışma" adlı yüksek lisans tez çalışmasının, güncellenerek yeniden ele alınmasıyla gerçekleştirilmiştir.

**Sorumlu yazar/Corresponding author

e-posta: basarozbozkurt@gmail.com
} 
Toplumsal yaşamın hızla değişmesi, sadece yöneticileri ve işletmeleri değil, çalışan bireylerin rol davranışlarını da değiştirmektedir. Bu değişimler, çalışanların iş hayatındaki rollerinde, rol belirsizliğine ve rol çatışmasına neden olmaktadır. Rol belirsizliği, genel olarak, çalışana verilen görev ve istenen performans sonucunda, çalışanın görev tanımına dair eksikliğinden kaynaklanmaktadır. Rol çatışması ise, çalışanın, birbiriyle çelişen talep ve beklentileri deneyimlemesiyle ortaya çıkmaktadır. Böyle bir durumda çalışan birey, bir talebi karşılarken, diğer talep ya da beklentileri karşılamakta güçlük çekmektedir (Fisher, 2001: 143).

$\mathrm{Bu}$ kapsamda çalışmada hastane gibi karmaşık bir organizasyon yapısında çalışan sağlık personelinin, rol belirsizliği ve rol çatışmasının iş performansına etkisini anlamak, iş tatminin aracılık rolünün ne düzeyde olduğunu belirlemek, sağlık personelinin performansını etkileyen koşullar hakkında bilgi sahibi olmak ve bu alandaki alanyazına katkıda bulunmak amaçlanmıştır. Bu amaç doğrultusunda, 2018 yılı içerisinde, Mersin ilindeki özel hastanelerde 400 sağlık çalışanı üzerinde anket uygulaması gerçekleştirilmiştir.

\section{Kuramsal Çerçeve}

\subsection{Rol Belirsizliği}

Rol belirsizliği, iş görenin iş ve görevlerini gerçekleştirirken, net olarak kendilerinden nelerin beklendiğini anlayamadıkları veya kendilerinden beklenenlerle neyin yapılması gerektiğine dair düşüncelerinin çelişmesi ile ortaya çıkmaktadır (Bernardin, 2010: 499). Rol belirsizliği, iş tanımlarının yeterli olmadığı çalışma ortamlarında yöneticilerin iş görenden net olmayan beklenti, emir veya istekleri ile iş görenin çalışma arkadaşlarının açık olmayan karmaşık davranışlarından ve sözlerinden kaynaklanabilmektedir (Griffin, 2008: 534).

Literatürde, görev belirsizliği ve sosyal-duygusal belirsizlik olmak üzere iki çeşit rol belirsizliğinden bahsedilmektedir. Organizasyon içinde çalışan birey, kendisine verilen görev ve rolünü yerine getirirken ihtiyaç duyduğu bilginin eksik ve açık olmaması durumunda görev belirsizliği ile karşılaşabilmektedir. Sosyal-duygusal belirsizlik olarak adlandırılan bir başka belirsizlik türü ise, iş görenin, görev ve sorumluluklarını yerine getirirken diğer insanlar tarafından nasıl değerlendirildiği hususunda yaşadığı belirsizlik olarak ifade edilebilmektedir.

\subsection{Rol Çatışması}

Her birey, kuruluşu oluşturan bir alana sahiptir ve bir görevi yerine getirmektedir. Kurum veya kuruluştaki diğer bireylerin de bu görev sahibi olan kişilerden rol beklentileri bulunmaktadır. Rol beklentilerinin tamamı, çalışanın rolünü tanımlayıp, belirlemektedir (Dozier, 2005: 350). Tersi durumlarda ise, kurum ya da kuruluş içinde rol, mevki ve yetki konusundan kaynaklanan çatışmalar ortaya ç1kabilmektedir (Gökçe ve Şahin, 2003: 134-135).

Rol çatışması, aynı anda iki veya daha fazla rol gönderiminden birine uyulması, diğer gönderime uyulmasının güçleşmesi gibi durumlarda ortaya çıkabilmektedir (Katz ve Kahn, 1977: 202). Çalışanın üstlendiği rollerin gerektirdiği görevler birbirleriyle çeliştiğinde rol çatışması meydana gelir. Rol çatışması, iş görenin birbirinden ilgisiz ve farklı görevi yerine getirmesi için yeterli çalışanın olmadığı durumlarda, üstler tarafından verilen bir görevi, kuralları uymayarak yerine getirmesi, organizasyonda farklı görevlere sahip grup çalışanlarıyla uyum sağlanamamasıyla artan bir durumdur (Başaran, 1982).

\section{3. İş Performans1}

Performans, çalışanın örgütsel amaç ve hedeflerini gerçekleştirmek üzere görev ve sorumlulukları ile ilgili faaliyetlerin ve bu çalışma sonucunda organizasyonların elde ettiği verim olarak ifade edilmektedir. Performans, amacın gerçekleştirilip görevin yerine getirilmesi yönünde ortaya konan düşünce, hizmet ya da üründür (Helvacı, 2002: 156).

Performans kavramı, küreselleşen dünya içerisinde yaşanmakta olan rekabet ortamından dolayı işletmelerin sürdürülebilirliği ve yenilikçi stratejiler geliştirebilmesi adına önemini artırmaya devam eden bir kavramdır. Temel amacı kâr elde etmek olan işletmelerin başarısı ve bu doğrultuda sürdürülebilirliği, iş görenin kaydettiği performans ve bu performansın ölçümüne bağlıdır. Organizasyonlarda yönetici tarafından iş görenin eksikleri ile yeteneklerinin bilinmesi ve tanınması, bu hususların ölçülmesi ve değerlendirilmesi performansı etkilemektedir (Üner, 2008: 343).

\section{4. İş Tatmini}

Genel olarak iş tatmini bireyin yapmakla yükümlü olduğu işe yönelik olarak geliştirdiği duygu ve davranışlar olarak ifade edilir. Çalışanların iş memnuniyeti, hizmetlerin iyileştirilmesinde önemli bir faktördür. Çalışanların yaşadıkları rol belirsizliği ve rol çatışması düzeyini azaltmak için organizasyonların, yönetici ve iş görenler arasında iyi bir iletişim ağı oluşturması ve çalışmadeğerlendirme sisteminin en üst seviyeye çıkarılması önem arz etmektedir. Örgütsel ortamlarını ve olanaklarını iyileştirmek, iş görenin bağlılığı üzerinde önemli bir etkendir (Nurdin, 2007: 223).

\subsection{Rol Belirsizliği ve Rol Çatışması İle İş Performansı Arasındaki İlişkiler}

İki veya daha fazlarol beklentisine aynı anda uyulması gerekliliği ve bu güçlüklerin oluşturduğu durumlarda ortaya çıkan rol belirsizliği ve rol çatışması durumları, bireylerin iş tatminsizliğine, başarısızlığına ve bunun sonucunda hem bireysel hem de kurumsal düzeyde performans düşüşüne neden olmaktadır (Katz ve Kahn, 1977: 202).

Literatürde, rol belirsizliği ve rol çatışması ile iş performansı arasında, negatif yönde anlamlı bir ilişkinin var olduğu belirtilmiştir (Fisher, 2001: 143). Ceylan ve Ulutürk (2006: 54), gerçekleştirmiş oldukları çalışmada, rol çatışması ve rol belirsizliğinin performans ve iş tatmini üzerindeki etkilerini azalttığı sonucuna ulaşmışlardır. Rol çatışması, ayrıca rol belirsizliğinin performans üstündeki etkilerini ortadan kaldırmaktadır. İki değişken birlikte ele alındığında rol belirsizliğinin performans biş tatmini üzerinde etkisi bulunmaktadır. 


\subsection{Rol Belirsizliği ve Rol Çatışması İle İş Tatmini Arasındaki İlişkiler}

Bireylerin rol belirsizlikleri ve rol çatışmaları, çalıştıkları kurumlarda tatminsizliğe sebep olabilmektedir. Eray (2017: 206), rol çatışması, rol belirsizliği, iş tatmini arasındaki ilişkileri incelediği araştırmasında, rol çatışmasının, rol belirsizliği ve iş tatmini üzerinde doğrudan bir ilișkisinin var olmadığı; ancak, rol belirsizliği ile iş tatmini arasında negatif yönlü anlamlı bir ilişki olduğu sonucunu ortaya çıkmıştır. Buna ek olarak, Börk ve Adıgüzel (2015: 258), araştırmalarında rol belirsizliği ve rol çatışmasının iş tatmini ile örgütsel bağll1ık üzerinde olumsuz yönde bir etkiye sahip olduğu sonucuna ulaşmıştır.

\section{7. İs Tatmini ile İș Performansı Arasındaki İlișkiler}

İş tatmini ile iş performans arasındaki ilişkinin anlamlı olabilmesi için çalışanın kişilik özellikleri, ödül beklentisi, eşitlik duygusu, bağlılık gibi destekleyici faktörlerin de var olması gerekmektedir. İş tatmini yüksek çalışanların, iş tatmini düşük çalışanlara oranla daha yüksek performans kaydedeceği düşünülmektedir (Akıncı, 2002: 8). İş tatmini ile örgütsel bağll1lk, iş görenin performansına olumlu yönde katk1 sağlayabilmektedir. Diğer taraftan, rol belirsizliği ile iş tatmininin alt faktörlerinden olan yönetim, terfi ve ücret imkânları arasında ise negatif yönde zayıf bir ilişki; rol belirsizliği ile işin kendisi arasında negatif yönde kuvvetli bir iliş̧inin olduğu tespit edilmiştir (Keller, 1975: 60).

\section{Evren ve Örneklem}

Araştırmanın evrenini Mersin ilindeki özel sağlık sektörü çalışanları oluşturmaktadır. Araştırmanın örneklemi, özel sağlık sektörü çalışanları arasından basit tesadüfî yöntem ile seçilen katılımcılardan oluşmaktadır. $\mathrm{Bu}$ kurumlarda yaklaşık 6000 kişi çalışmaktadır. Sekaran (1992: 253), evrene göre örneklem sayısının belirlenmesine ilişkin çalışmasında, 6000 kişiden oluşan bir evren için, ana kütleden $\% 95$ güvenilirlik sınırları içerisinde $\% 5$ 'lik bir hata payı dikkate alınarak örneklem büyüklüğünün 361 olması gerektiğini ifade etmiştir. Bu kapsamda, basit tesadüfî örnekleme yöntemiyle seçilen toplam 600 kişiye anket yapılması planlanmış olup gönderilen anketlerden 444 tanesi geri dönmüş ve 412 tanesi analiz yapmak için uygun bulunmuştur. Yapılan uç değer analizinde değişkenlere ait normal dağılımı bozan 12 veri seti çıkartılmış ve 400 katılımcının doldurduğu anket analizlere dâhil edilmiștir. Araştırma katılımcılarına ait demografik bilgilere (eğitim durumu, cinsiyet ve medeni hal, ortalama yaş ve çalışma süresi) aşağıda yer verilmiştir.

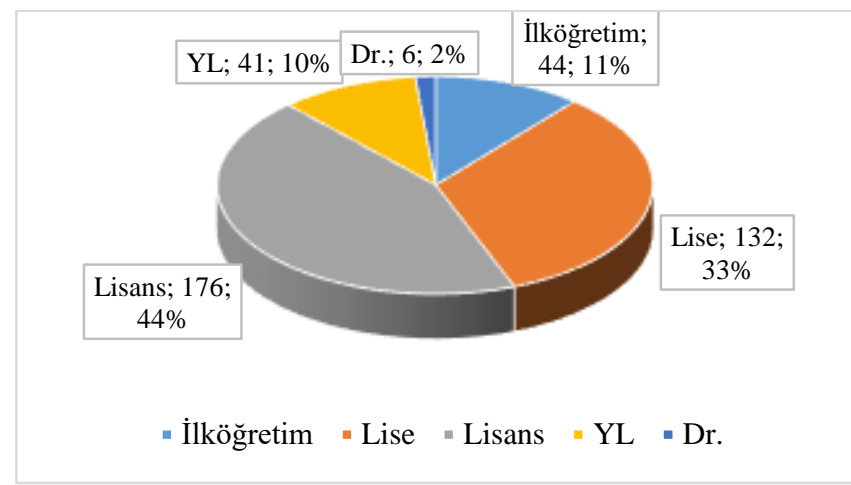

Şekil 1. Eğitim Durumu

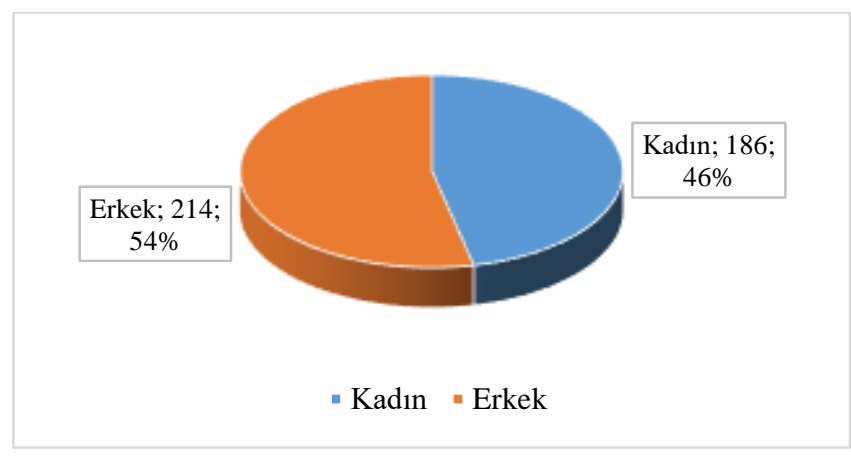

Şekil 2. Cinsiyet

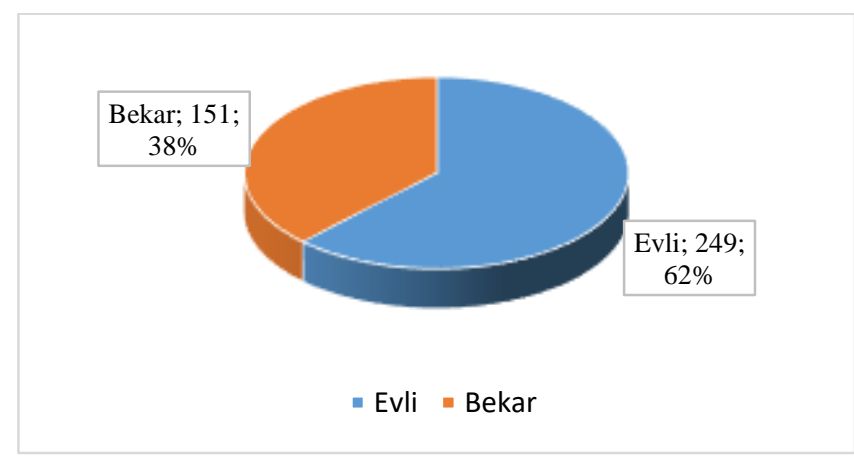

Şekil 3. Medeni Hal

Tablo 1. Betimleyici İstatistikler

\begin{tabular}{lcc}
\hline & Yaş & $\begin{array}{c}\text { Çalışma } \\
\text { Süresi(yıl) }\end{array}$ \\
\hline Ortalama & 34,82 & 10,34 \\
St. Sapma & 8,68 & 7.25 \\
Minimum & 20 & 1 \\
Maksimum & 61 & 45 \\
\hline
\end{tabular}

\section{Veri Toplama Aracı}

Araştırmada veri toplama aracı olarak anket tekniği uygulanmıştır. $\mathrm{Bu}$ kapsamda anketler; tabip, hemşire, sağlık teknikeri ve diğer sağlık çalışanlarından oluşan katılımcılara yüz yüze uygulanmıştır. Anket formu iki bölümden ve toplam 28 ifadeden oluşmaktadır. Birinci bölümde demografik değişkenlerle ilgili 5 ifade yer almaktadır. İkinci bölümde ise toplamda 23 ifadeden oluşan Rol Belirsizliği, 6 madde; Rol Çatışması, 8 madde; İş Tatmini, 5 madde; İş Performansı, 4 maddeden oluşan ölçekler bulunmaktadır. Ölçeklerin Cronbach alfa güvenirlik katsayıları "SPSS 23.0" paket programı ile 
doğrulayıcı faktör analizleri ise AMOS 23.0 programı ile analiz edilmiştir.

Rol belirsizliği (RB) ve rol çatışmasının (RÇ), bireylerin iş performansı (IIP) üzerine etkisini ve bu etkide iş tatmininin (IT) aracılık rolünü belirlemeye yönelik olan bu araştırmada kullanılan ölçeklere ilişkin bilgiler aşağıda verilmektedir.

\subsection{Rol Belirsizliği Ölçeği (RB)}

Özel sağlık sektörü çalışanlarının algılanan rol belirsizlik düzeylerini belirlemek üzere Rizzo, House ve Lirtzman (1970: 150) tarafından geliştirilen ve daha sonra Schuler, Aldag ve Brief (1977: 114) ve House, Schuler ve Levanoni (1983: 334) tarafindan kullanılan 6 maddeli ölçek kullanılmıştır. Bu ölçeğin Rizzo vd. (1970: 150) tarafından yapılan güvenirlik analizi sonucunda ölçeğin Cronbach alfa güvenirlik katsayısı .87 olarak bulunmuştur. Sorular "Ne kadar yetkiye sahip olduğumu biliyorum.", "İşimle ilgili belirgin, planlanmış hedefler ve amaçlar vardır." şeklindedir. Ölçekte cevaplar 5'li likert ölçeği ile alınmıştır (1=Kesinlikle katılmıyorum, 5=Kesinlikle katılıyorum). Çalışmada ölçeğin yapı geçerliliğini test etmek maksadıyla keşfedici faktör analizi yapılmış, verilerin, ölçeğin tek faktörlü yapısına uyum sağladığı belirlenmiştir. Ölçeğin faktör yüklerinin .87 ile .76 arasında olduğu, KMO analiz sonucu .89 ve Barlett testi anlamlı $(p=.000)$ olarak tespit edilmiştir. Ardından Amos paket programı ile doğrulayıcı faktör analizi yapılmış, verilerin, ölçeğin tek faktörlü yapısına uyum sağladığı ve faktör yüklerinin .85 ile .73 arasında olduğu tespit edilmiştir. Ölçeğin uyum iyiliği değerleri, diğer ölçeklerinki ile birlikte Tablo 4'te sunulmuştur. Yapılan güvenirlik analizi sonucunda ölçeğin Cronbach alfa güvenirlik katsayısı .81 olarak bulunmuştur.

\subsection{Rol Çatışması Ölçeği (RÇ)}

Özel sağlık sektörü çalışanlarının algılanan rol belirsizlik düzeylerini belirlemek üzere Rizzo vd. (1970: 150) tarafindan geliştirilen, daha sonra Schuler vd. (1977: 114) ve House vd. (1983: 334) tarafindan kullanılan 8 maddeli ölçek kullanılmıştır. Bu ölçeğin Rizzo vd. (1970: 150) tarafından yapılan güvenirlik analizi sonucunda ölçeğin Cronbach alfa güvenirlik katsayısı .82 olarak bulunmuştur. Toplam sekiz ifadeden oluşan ölçekte sorular "Birbirinden farklı şekillerde yapılması gereken işleri yapmak zorunda kalıyorum.", "Görevimi başarmak için bazı karar ya da kurallara göre ters hareket etmek zorunda kalıyorum." şeklindedir. Ölçekte cevaplar 5'li likert ölçeği ile alınmıştır (1=Kesinlikle katılmiyorum, 5=Kesinlikle katılıyorum). Çalışmada ölçeğin yapı geçerliliğini test etmek maksadıyla keşfedici faktör analizi yapılmış, verilerin ölçeğin tek faktörlü yapısına uyum sağladığı belirlenmiştir. Ölçeğin faktör yüklerinin .83 ile .71 arasında olduğu, KMO analiz sonucu .88 ve Barlett testi anlaml $(\mathrm{p}=.000)$ olarak tespit edilmiştir. Takiben Amos paket programı ile doğrulayıcı faktör analizi yapılmış, verilerin ölçeğin tek faktörlü yapısına uyum sağladığı ve faktör yüklerinin .80 ile .72 arasında olduğu tespit edilmiştir. Ölçeğin uyum iyiliği değerleri diğer ölçeklerinki ile birlikte Tablo 2'de sunulmuştur. Yapılan güvenirlik analizi sonucunda ölçeğin toplam Cronbach alfa güvenirlik katsayısı .80 olarak bulunmuş ve bu değerlere Tablo 4'te yer verilmiştir.

\section{3. ̇̇ş Tatmini Ölçeği (İT)}

Özel sağlık sektöründe çalışan bireylerin iş tatmin düzeylerini belirlemek üzere Arnett (1999) ile Judge, Woolf ve Hurst, (2009: 68) tarafindan geliştirilen 5 maddeli ölçek kullanılmıştır. Bu ölçeğin Türkçe geçerlemesi Çalışkan, Akkoç ve Turunç (2011: 378) tarafından yapılmış ve güvenirlik analizi sonucunda ölçeğin Cronbach alfa güvenirlik katsayısı .81 olarak bulunmuştur. Toplam beş ifadeden oluşan ölçekte sorular "İşimden tatmin olduğumu hissediyorum.", "Bu kurumda uzun süre çalışacağımı düşünüyorum.” ş̧eklindedir. Ölçekte cevaplar 5'li likert ölçeği ile alınmıştır (1=Kesinlikle katılmıyorum, 5=Kesinlikle katılıyorum). Çalışmada ölçeğin yap1 geçerliliğini test etmek maksadıyla keşfedici faktör analizi yapılmış, verilerin ölçeğin tek faktörlü yapısına uyum sağladığı belirlenmiştir. Ölçeğin faktör yüklerinin .84 ile .77 arasinda olduğu, KMO analiz sonucu .89 ve Barlett testi anlamlı $(p=.000)$ olarak tespit edilmiştir. Ardından Amos paket programı ile doğrulayıcı faktör analizi yapılmış, verilerin ölçeğin tek faktörlü yapısına uyum sağladığı ve faktör yüklerinin .83 ile .71 arasında olduğu tespit edilmiştir. Ölçeğin uyum iyiliği değerleri diğer ölçeklerinki ile birlikte Tablo 2'de sunulmuştur. Yapılan güvenirlik analizi sonucunda ölçeğin toplam Cronbach alfa güvenirlik katsayısı .77 olarak bulunmuş ve bu değerlere Tablo 4'te yer verilmiştir.

\section{4. İş Performansı Ölçeği (İP)}

Özel sağlık sektörü çalışan bireylerin iş performanslarını belirlemek üzere önce Kirkman ve Rosen (1999: 66), daha sonra ise, Sigler ve Pearson (2000) tarafından kullanılan iş performansı ölçeği kullanılmıştır. Dört sorudan oluşan ölçekte sorular "İşimde göstermiş olduğum performans düzeyim yüksektir." ve "İş hedeflerime fazlasıyla ulaşırım." şeklindedir. Ölçeğin güvenirlik katsayısı her iki çalışmada da .70'in üstündedir. Türkiye'de, Çöl (2008: 42) tarafindan akademisyenler üzerinde uygulanan ölçeğin güvenirlik katsayısı .82 olarak tespit edilmiştir. Ölçekte cevaplar 5'li likert ölçeği ile alınmıştır (1=Kesinlikle katılmıyorum, 5=Kesinlikle katılıyorum). Çalışmada ölçeğin yap1 geçerliliğini test etmek maksadıyla keşfedici faktör analizi yapılmış, verilerin ölçeğin tek faktörlü yapısına uyum sağladığı belirlenmiştir. Ölçeğin faktör yüklerinin .91 ile .85 arasında olduğu, KMO analiz sonucu .88 ve Barlett testi anlamlı $(p=.000)$ olarak tespit edilmiştir. Ardından Amos paket programı ile doğrulayıcı faktör analizi yapılmış, verilerin ölçeğin tek faktörlü yapısına uyum sağladığı ve faktör yüklerinin .86 ile .78 arasında olduğu tespit edilmiştir. Ölçeğin uyum iyiliği değerleri diğer ölçeklerinki ile birlikte Tablo 2'de sunulmuştur. Yapılan güvenirlik analizi sonucunda ölçeğin toplam Cronbach alfa güvenirlik katsayısı .85 olarak bulunmuş ve bu değerlere Tablo 4'te yer verilmiştir. 
Tablo 2. Doğrulayıcı Faktör Analizi Sonucunda Ölçeklerin Uyum İyiliği Değerleri

\begin{tabular}{|c|c|c|c|c|c|c|c|c|c|}
\hline $\begin{array}{c}\text { Değiş̧e } \\
\text { nler }\end{array}$ & $\mathbf{X}^{2}$ & df & $\begin{array}{c}\text { CMI } \\
\text { N/ } \\
\text { DF } \\
\leq 5 \\
\end{array}$ & $\begin{array}{l}\text { GFI } \\
\geq .85\end{array}$ & $\begin{array}{c}\text { AGF } \\
\text { I } \\
\geq .80\end{array}$ & $\begin{array}{l}\text { CFI } \\
\geq .90\end{array}$ & $\begin{array}{l}\text { NFI } \\
\geq .90\end{array}$ & $\begin{array}{l}\text { TLI } \\
\geq .90\end{array}$ & $\begin{array}{c}\text { RMS } \\
\text { EA } \\
\leq .08\end{array}$ \\
\hline 1.RB & 28.4 & 14 & 3.14 & $\begin{array}{c}0.8 \\
6\end{array}$ & $\begin{array}{c}0.8 \\
7\end{array}$ & $\begin{array}{c}0.9 \\
1\end{array}$ & $\begin{array}{c}0.9 \\
4\end{array}$ & 0.93 & 0.03 \\
\hline 2. $\mathbf{R C}$ & 12.5 & 1 & 3.4 & $\begin{array}{c}0.9 \\
4\end{array}$ & $\begin{array}{c}0.9 \\
9\end{array}$ & $\begin{array}{c}1.0 \\
0\end{array}$ & $\begin{array}{c}1.0 \\
0\end{array}$ & 1.00 & 0.00 \\
\hline 3. İT & $\begin{array}{c}125 . \\
3\end{array}$ & 44 & 2.9 & $\begin{array}{c}0.9 \\
3\end{array}$ & $\begin{array}{c}0.9 \\
3\end{array}$ & $\begin{array}{c}0.9 \\
6\end{array}$ & $\begin{array}{c}0.9 \\
7\end{array}$ & 0.94 & 0.03 \\
\hline 4. İP & $\begin{array}{c}101 . \\
4\end{array}$ & 69 & 1.5 & $\begin{array}{c}0.9 \\
3\end{array}$ & $\begin{array}{c}0.9 \\
6\end{array}$ & $\begin{array}{c}0.9 \\
4\end{array}$ & $\begin{array}{c}0.9 \\
7\end{array}$ & 0.94 & 0.06 \\
\hline
\end{tabular}

Not:Uyum iyiliği değer aralıkları "kabul edilebilir" standartlara göre düzenlenmiştir.

\section{Bulgular ve Yorumlar}

\subsection{Değişkenlerle İlgili Betimleyici Bulgular}

Araştırmada 400 katılımcıdan elde edilen betimleyici istatistiklere göre kullanılan bağımlı ve bağımsız değişkenlere ilişkin (en küçük, en büyük ve ortalama) değerler, Tablo 3'te verilmiştir. Araştırmanın bağımsız değişkenleri olan rol belirsizliği ve rol çatışması ölçeklerinde yer alan toplam 14 madde için aritmetik ortalamalar alınarak analizler yapılmıştır. Diğer bağımsız değişken iş tatmini, faktör analizi sonucu belirlenen 5 maddenin aritmetik ortalaması hesaplanarak belirlenmiştir. Bağımlı değişken olan iş performansı ise toplam 4 madde faktör analizi sonucu belirlenen tek boyut olarak aritmetik ortalaması hesaplanarak belirlenmiştir. Hesaplamalarda en düşük puan 1 (bir), en yüksek puan ise, 5 (beş) olmak üzere puanlama beş puan üzerinden yapılmıştır. Sonuçlar Tablo 3 'te gösterilmiştir.

Tablo 3. Değişken ve Boyutlarına İlişkin Betimleyici İstatistikler

\begin{tabular}{lccc}
\hline Değişkenler & Toplam & Ortalama & Std. Sapma \\
\hline Rol Belirsizliği & 400 & 3.51 & 0.87 \\
Rol Çatışması & 400 & 3.18 & 0.78 \\
İş Tatmini & 400 & 3.38 & 0.81 \\
İş Performans1 & 400 & 3.49 & 0.79 \\
\hline
\end{tabular}

\subsection{Değişkenler Arası İlişkiler}

Değişkenler arasındaki ilişkileri belirlemek amacıyla Pearson korelasyonları hesaplanmıştır (Tablo 4). Tabloda ayrıca satırların sonunda güvenilirlik bulguları parantez içinde sunulmuştur. Analiz sonucunda; çalışanların iş performansının, rol belirsizliği ve rol çatışması ile negatif, aracı değişken olarak belirlenen iş tatmini ile pozitif yönde anlamlı bir ilişkiye sahip olduğu görülmektedir.
Tablo 4. Değişkenler Arası Korelasyon Değerleri

\begin{tabular}{lcccc}
\hline Değişkenler & $\mathbf{1}$ & $\mathbf{2}$ & $\mathbf{3}$ & $\mathbf{4}$ \\
\hline $\mathbf{1 . R B}$ & $\mathbf{( . 8 1 )}$ & & & \\
2.RÇ & $.48^{* *}$ & $\mathbf{( . 8 0 )}$ & & \\
$\mathbf{3 . I T}$ & $-.73^{* *}$ & $-.55^{* *}$ & $\mathbf{( . 7 7 )}$ & \\
4.İP & $-.81^{* *}$ & $-.53^{* *}$ & $.70 * *$ & $\mathbf{( . 8 5 )}$ \\
\hline Not: Alfa güvenilirlik & katsayıları & parantez & içinde \\
gösterilmiştir. & & & & \\
$* * p<.01$, & & & & \\
\end{tabular}

\subsection{Demografik Gruplardaki Farkl11ıklar}

Araştırmada bağımlı değişken olan iş performansının, cinsiyete, medeni duruma, göre farklılık gösterip göstermediği "t-testi”; çalışanların eğitim durumuna göre farkl1lık gösterip göstermediği ise "ANOVA analizi” ile test edilmiştir.

İş performansının cinsiyete, medeni duruma göre farklılık gösterip göstermediğini test etmek üzere yapılan t-testi sonucunda (Tablo 5) özel sağlık sektörü çalışanlarının iş performanslarının cinsiyete göre farklılaşmadığı, ancak medeni duruma göre farklılaştığı tespit edilmiştir. Farklı bir ifadeyle, özel sağlık sektörü çalışanlarının iş performanslarının medeni duruma göre evlilerin lehine anlamlı bir fark oluşturduğu, evli çalışanların bekâr çalışanlara oranla algılanan performanslarının daha yüksek olduğu tespit edilmiştir.

Tablo 5. T Testi Bulguları

\begin{tabular}{cccccc}
\hline Değişken & Grup & N & Ort. & SS & Sig \\
\hline \multirow{2}{*}{ İş } & Kadın & 186 & 3.56 & .84 & .14 \\
Performansı & Erkek & 214 & 3.43 & .91 & \\
& Evli & 249 & 3.58 & .87 & .02 \\
& Bekâr & 151 & 3.36 & .86 & \\
\hline
\end{tabular}

$* \mathrm{p}<.05$

Özel sağlık sektörü çalışanlarının iş performanslarının eğitim durumuna göre farklılık gösterip göstermediği ise "ANOVA analizi" ile test edilmiştir. İş performansının eğitim durumuna göre farklılık gösterip göstermediğini belirlemek üzere yapılan tek yönlü ANOVA analizleri Tablo 6'da sunulmuştur. $\mathrm{Bu}$ doğrultuda, çalışanların iş performansları, eğitim seviyelerine göre farklılık göstermektedir $(\mathrm{F}=5,802, \mathrm{p}>0,01)$. Farklılaşan grupları tespit etmek amacıyla Tukey testi yapılmıştır. Tukey testi sonuçlarına göre farklılıkların, lisans-ilköğretim ve lisanslise gruplarında olduğu tespit edilmiştir. 
Tablo 6.ANOVA Testi Bulguları

\begin{tabular}{lllllll}
\multicolumn{1}{c}{ Değişken } & Grup & N & Ort. & SS & F & Sig. \\
\hline & İlköğretim & 44 & 3.18 & .83 & & \\
& Lise & 133 & 3.30 & .89 & & \\
\multirow{2}{*}{ İş Performansı } & Lisans & 176 & 3.68 & .85 & 5.802 & .000 \\
& Y. Lisans & 41 & 3.68 & .80 & & \\
& Doktora & 6 & 3.42 & .66 & & \\
\hline
\end{tabular}

5.4. Çalışanların İş Performansını Yordayan Değişkenler: Regresyon Analizi Bulguları

Değişkenler arası doğrudan ilişkileri, farklı bir ifadeyle bağımsız değişkenlerin bağımlı değişkenler üzerindeki açıklama güçlerini ortaya koymak amacıyla regresyon analizleri yapılmıştır. Regresyon analizlerinde çalışanların iş performansları bağımlı değişken olarak ele alınmış, rol belirsizliği ve rol çatışması ile aracı değişken olarak belirlenen iş tatmini, bağımsız değişkenler olarak ele alınarak, bağımlı değişken üzerindeki etkileri incelenmiştir.

Rol belirsizliği (RB) ile rol çatışmasının (RÇ), iş performansı (IP) üzerine etkisini ve bu etkide iş tatmininin (IT) aracılık rolünü açıklamak amacıyla, Baron ve Kenny (1986: 1179) tarafindan önerilen üç aşamalı regresyon analizi yapılmıştır. Bu yönteme göre, bağımsız değişkenin bağımlı değişken ve aracı değişken üzerinde bir etkisi olması gerekmektedir. Aracı değişken bağımsız değişkenle birlikte regresyon analizine dâhil edildiğinde, bağımsız değişkenin bağımlı değişken üzerindeki regresyon katsayısı düşerken, aracı değişkenin de bağımlı değişken (İP) üzerinde anlamlı etkisi sürmesi gerekmektedir. Bu kapsamda, İT düzeyinin aracılık rolünü belirlemek amacıyla, RB-İT, İP ve RÇ-İT, İP arasındaki ilişkiler hiyerarşik regresyon analizleri aracılığı ile incelenmiş ve Sobel testleri yapılmıştır. Aracılık testine ilişkin bulgular "Tablo 7", "Tablo 8" ve "Tablo 9"da verilmiştir.

Aracılık testi kapsamında ilk aşamada bağımsız değişken rol belirsizliği ile iş performansı arasındaki ilişkilere bakılmıştır. Bu aşamanın ilk adımında RB'nin İP'yi ( $\beta=$ $.81, \mathrm{p}<.01)$ anlamlı olarak etkilediği görülmüştür. İkinci adımda RB'nin aracılığı araştırılan İT'ye olan etkisi incelenmiştir. Analiz sonucunda, RB'nin İT'yi anlamlı olarak etkilediği $(\beta=-.73, p<.01)$ tespit edilmiştir. $\mathrm{Bu}$ adımda aracılığı araştırılan IT'nin İP'ye olan etkilerine de bakılarak rapor edilmiştir. İT'nin İP'yi $(\beta=.70, p<.01)$ anlamlı olarak etkilediği bulgulanmıştır. $\mathrm{Bu}$ aşamanın son adımında ise RB ve aracılığ 1 araştırılan IT birlikte analize sokulmuş ve İP üzerindeki etkilerine bakılmıştır. Bu analiz sonucunda, RB'nin İT ile birlikte analize sokulmasıyla İP üzerindeki etkisi devam etmiş ve azalmış $(\beta=-.60, \mathrm{p}<.01)$, ITT'nin de İP üzerindeki etkisi devam etmiştir $(\beta=.48$, $\mathrm{p}<.01$ ). Bu şartların sağlanmasının ardından aracılık etkisini teyit etmek maksadıyla Sobel testi yapılmış ve Sobel(z) anlamlı bulunmuştur $(\mathrm{z}=4,3, \mathrm{p}<.01)$. Bu bulgu RB'nin IP'ye etkisinde İT'nin kısmi aracılık rolü üstlendiğini göstermektedir. $\mathrm{Bu}$ bölüm analizleri sonucunda $\mathrm{H}_{1}, \mathrm{H}_{3}, \mathrm{H}_{5}$ ve aracılık hipotezi olan $\mathrm{H}_{6}$ 'nın desteklendiği görülmektedir.
Aracılık testinin ikinci aşamasında, ikinci bağımsız değişken rol çatışması ile iş performansı arasındaki ilişkilere bakılmıştır. Bu aşamanın ilk adımında, RÇ'nin IP'yi $(\beta=-.53, p<.01)$ anlamlı olarak etkilediği görülmüştür. İkinci adımda RÇ'nin aracılığı araştırılan IT'ye olan etkisi araştırılmıştır. Analiz sonucunda RÇ’nin İT'yi anlamlı olarak etkilediği $(\beta=-.55, p<.001)$ tespit edilmiştir. $\mathrm{Bu}$ aşamanın son adımında ise, RÇ ve aracılığı araştırılan IT birlikte analize sokulmuş ve İ üzerindeki etkilerine bakılmıştır. Bu analiz sonucunda RÇ’nin İT ile birlikte analize sokulmasıyla, İP üzerindeki etkisi devam etmiş ve azalmış $(\beta=-.31, p<.01)$, İT'nin de İP üzerindeki etkisi devam etmiştir $(\beta=.22, \mathrm{p}<.01)$. Bu şartların sağlanmasının ardından aracılık etkisini teyid etmek maksadıyla Sobel testi yapılmış ve Sobel (z) anlamlı bulunmuştur ( $\mathrm{z}=7.3$, $\mathrm{p}<.01)$. Bu bulgu da RÇ'nin İP'ye etkisinde İT'nin kısmi aracılık rolü üstlendiğini göstermektedir. $\mathrm{Bu}$ bölüm analizleri sonucunda $\mathrm{H}_{2}, \mathrm{H}_{4}$ ve aracılık hipotezi olan $\mathrm{H}_{7}$ 'nin desteklendiği görülmektedir. $\mathrm{Bu}$ sonuçla, regresyon analizleri ile test edilen toplam 7 hipotezin tamamı destek bulmuştur.

Tablo 7.Aracılık Testi Sonuçları (RB-İT-İP)

\begin{tabular}{|c|c|c|c|}
\hline & & \multicolumn{2}{|c|}{$\beta$} \\
\hline & & İT & IP \\
\hline \multicolumn{4}{|c|}{ Test 1} \\
\hline & Yaş & & -.09 \\
\hline & Çal.Süresi & & .09 \\
\hline & $\mathbf{R B}$ & & $-.81 * *$ \\
\hline & Adjusted $\mathrm{R}^{2}$ & & .65 \\
\hline & $\Delta R^{2}$ & & .65 \\
\hline & & & $(F=734 * *)$ \\
\hline & Test 2 & & $\mathbf{I} \mathbf{T} \rightarrow \mathbf{I P}$ \\
\hline & Yaş & -.56 & .04 \\
\hline & Çal.Süresi & .01 & -.22 \\
\hline & RB & $.74 * *$ & $.69 * *$ \\
\hline \multirow[t]{12}{*}{ RB } & Adjusted $\mathrm{R}^{2}$ & .54 & .48 \\
\hline & $\Delta R^{2}$ & .53 & .48 \\
\hline & & $(F=454 * *)$ & $(F=365 * *)$ \\
\hline & \multicolumn{3}{|l|}{ Test 3} \\
\hline & Yaş & & -.005 \\
\hline & Çal.Süresi & & -.32 \\
\hline & RB & & $-.60 * *$ \\
\hline & İT & & $.48 * *$ \\
\hline & Adjusted $\mathrm{R}^{2}$ & & .33 \\
\hline & $\Delta R^{2}$ & & .33 \\
\hline & & & $(F=125 * *)$ \\
\hline & Sobel Test(z) & \multicolumn{2}{|c|}{$4.3 * *$} \\
\hline
\end{tabular}

$* * \mathrm{p}<.01$ 
Tablo 8. Aracıılı Testi Sonuçları (RÇ-İT-İP)

\begin{tabular}{|c|c|c|c|}
\hline & & \multicolumn{2}{|c|}{$\beta$} \\
\hline & & ITT & İP \\
\hline \multicolumn{4}{|c|}{ Test 1} \\
\hline & Yaş & & -.14 \\
\hline & Cal.Süresi & & .006 \\
\hline & $\mathbf{R C ̧}$ & & $-.53 * *$ \\
\hline & Adjusted $\mathrm{R}^{2}$ & & .28 \\
\hline & $\Delta R^{2}$ & & .28 \\
\hline & & & $(F=154 * *)$ \\
\hline & Test 2 & & \\
\hline & Yaş & -.18 & \\
\hline & Çal.Süresi & .005 & \\
\hline & RÇ & $-.55 * *$ & \\
\hline \multirow[t]{12}{*}{ RÇ } & Adjusted $\mathrm{R}^{2}$ & .30 & \\
\hline & $\Delta R^{2}$ & .30 & \\
\hline & & $\left(F=168^{* *}\right)$ & \\
\hline & Test 3 & & \\
\hline & Yaş & & -.18 \\
\hline & Çal.Süresi & & .05 \\
\hline & RÇ & & $-.31 * *$ \\
\hline & İT & & $.22 * *$ \\
\hline & Adjusted $\mathrm{R}^{2}$ & & .19 \\
\hline & $\Delta R^{2}$ & & .19 \\
\hline & & & $(F=228 * *)$ \\
\hline & Sobel Test $(z)$ & \multicolumn{2}{|c|}{$7.3 * *$} \\
\hline
\end{tabular}

Tablo 9. Aracılık Testi Sonuçları

\begin{tabular}{|c|c|}
\hline HIPOTEZLER & SONUÇ \\
\hline $\begin{array}{l}\text { H1: Rol belirsizliği, bireylerin iş } \\
\text { performansını negatif ve anlaml } \\
\text { olarak etkiler. }\end{array}$ & Desteklendi \\
\hline $\begin{array}{l}\mathbf{H}_{2} \text { : Rol çatışması, bireylerin iş } \\
\text { performansını negatif ve anlaml } \\
\text { olarak etkiler. }\end{array}$ & Desteklendi \\
\hline $\begin{array}{l}\text { H3: Rol belirsizliği, bireylerin iş } \\
\text { tatminini negatif ve anlaml } \\
\text { olarak etkiler. }\end{array}$ & Desteklendi \\
\hline $\begin{array}{l}\text { H4: Rol çatışması, bireylerin iş } \\
\text { tatminini negatif ve anlaml } \\
\text { olarak etkiler. }\end{array}$ & Desteklendi \\
\hline 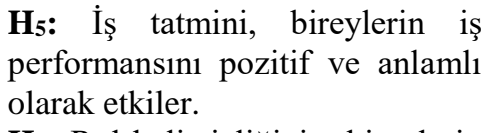 & Desteklendi \\
\hline $\begin{array}{l}\text { Ho }_{6} \text { Rol belirsizliğinin, bireylerin } \\
\text { iş performans1 üzerine etkisinde } \\
\text { iş tatmininin aracılık rolü vardır. }\end{array}$ & Desteklendi \\
\hline $\begin{array}{l}\text { H7 }_{7} \text { Rol çatışmasının, bireylerin } \\
\text { iş performansı üzerine etkisinde } \\
\text { iş tatmininin aracılık rolü vardır. }\end{array}$ & Desteklendi \\
\hline
\end{tabular}

\section{Sonuç ve Öneriler}

Özel sağlık kuruluşlarında görev yapmakta olan sağlık çalışanlarının rol çatışması ve rol belirsizliği yaşayıp yaşamadıkları, görevleri ve gerçekleştirmesi gereken roller hakkında gerekli bilgiye sahip olup olmadıklarını belirlemek amacı ile yapılan bu çalışmada; değişkenler arasındaki ilişkiyi belirlemek suretiyle Pearson korelasyonları hesaplanmıștır. Analiz sonucunda, çalışanların iş performansının, rol belirsizliği ve rol çatışması ile negatif; aracılık rolüne sahip değişken olan iş tatmini ile ise pozitif yönde anlamlı bir ilişkiye sahip olduğu görülmektedir.

Araştırmada, bağımlı değişken olan iş performansının, cinsiyete ve medeni duruma göre farklılık gösterip göstermediğinin incelenmesi amaciyla gerçekleştirilen ttesti sonucunda, özel sağlık sektörü çalışanlarının iş performanslarının cinsiyete göre farklılaşmadığı, ancak medeni duruma göre farklılaştı̆̆ görülmüştür. $\mathrm{Bu}$ bağlamda, evli bireylerin bekâr olanlara göre algılanan iş performanslarının daha yüksek olduğu tespit edilmiştir. Buradan hareketle medeni durumun cinsiyet gözetmeksizin, çalışanların iş performanslarına etki etmesinde Özmutaf (2007: 49)'ın da belirttiği üzere, olumlu yönde devam eden evliliklerin, çalışanların iş performansına pozitif yönde katk1 sağlamış olabileceği ve bu bağlamda, özel sağlık sektöründe çalışan bireylerde de bu olumlu etkinin görülmüş olabileceği çıkarımında bulunulabilmektedir.

Özel sağlık kuruluşu çalışanlarının, iş performanslarının eğitim durumuna göre farklılık gösterip göstermediğinin incelenmesi amacıyla gerçekleştirilmiş Tukey testi sonucunda, iş performanslarının, eğitim seviyelerine göre farklılık kaydettiği, bunun ise lisans-ilköğretim ve lisanslise gruplarında meydana geldiği; lisans öğrencilerinin iş performansının, lise ve ilköğretim mezunlarına göre anlamlı düzeyde daha yüksek olduğu saptanmıştır. Çalışanların eğitim seviyeleri arttıkça iş hayatındaki tatmin düzeylerinde de artış meydana gelebileceği, bu durumun ise iş performansını artırıcı yönde etki gösterdiği düşünüldüğünde, bahse konu eğitim grupları arasında eğitim seviyesi arttığında iş performansında da artış gerçekleşebileceği ifade edilebilmektedir.

Diğer taraftan, bağımsız değişkenlerin, bağımlı değişkenler üzerinde etkilerini test etmek üzere gerçekleştirilen regresyon analizlerinde ise bağımlı değişken olan iş performansının, bağımsız değişkenler olan rol belirsizliği, rol çatışması ve aracı değişken olan iş tatmini üzerindeki etkisinin incelenmesi çerçevesinde, sobel testler ve aracilık testi kapsamında, ilk aşamada rol belirsizliğinin iş performansı üzerinde anlamlı ve negatif yönde bir etkisinin olduğu sonucuna ulaşılmıştır. Buradan hareketle, çalışanların deneyimlediği rol belirsizliğini gidermek suretiyle yöneticilere büyük görev düşmekte olup; böylece çalışanların performanslarında olumlu etkinin kaydedilmesi ve bulundukları kuruluşlara da daha önemli katkılar sağlayabilecekleri düşünülmektedir.

Rol çatışması ile iş performansı arasındaki ilişsi ele alındığında ise, aralarında anlamlı bir etkinin mevcut olduğundan ve bu araştırmanın, iş performansını etkileyen rol belirsizliği ve rol çatışmasının, iş tatmini üzerindeki etkisinin ortaya konulmuş olduğu söylenebilmektedir. Ayrıca, bu sonuçla birlikte, regresyon analizleri ile test edilen 7 hipotezin tamamı desteklenmiştir.

Mersin ilinde faaliyet gösteren özel sağlık kuruluşu çalışanları üzerinde gerçekleştirilen bu araştırma kapsamında sınırlı sayıda katılımcıya ulaşııldığından, ortaya çıkan sonuçların genellenebilirlikten ziyade literatüre katkıda bulunacağı düşünülmektedir. Buna ek olarak, veri toplarken sadece katılımcıların beyan ve kişisel değerlendirmelerine dayalı yöntemlerin kullanılmış olması, genelleme yapmaya çok fazla olanak sağlamamaktadır. 
Gelecekteki ilgili çalışmalarda, özel hastanelere ek olarak devlet hastanelerinin de dâhil edilmesi ve daha kapsamlı bir çalışmanın gerçekleştirilmesi önerilmektedir. Diğer taraftan, özel sağlık kuruluşlarında, tüm çalışanların iş tanımlarının net ve rol çatışmasına yol açmayacak şekilde olması ve sağlık çalışanlarının performans artışına zemin hazırlayacak ilgili ek birimlerin oluşturulması tavsiye edilmektedir. Böylece, iş tatmini ve performansı artacak olan özel sağlık çalışanlarının, iş hayatlarında daha verimli olacağı düşünülmektedir.

\section{Kaynakça}

Akıncı, Z. (2002). “Turizm Sektöründe işgörenin İş tatminini etkileyen faktörler: beş yıldızlı konaklama işletmelerinde bir uygulama", Akdeniz Üniversitesi I.I.B.F. Dergisi, 4, 1-25.

Arnett, J. J. (1999). "Adolescent Storm And Stress, Revisited", American Psychologist, 54(5), 317-326.

Baron, R. M. \& Kenny, D. A. (1986), The ModeratorMediator Variable Distinction İn Social Psychological Research: Conceptual, Strategic, And Statistical Considerations. Journal Of Personality And Social Psychology, 51, 1173-1182.

Başaran, İ. E. (1982). Örgütsel Davranışın Yönetimi.Ankara: Ankara Üniversitesi Eğitim Fakültesi.

Bernardin, H. J. ( 2010). Human resource manegement : an experiential approach. New York: The McGraw-Hill Companies Inc.

Börk, A. \& Adıgüzel, O. (2015). Rol Çatışması ve Rol Belirsizliğinin İş Tatmini ve Örgütsel Bağl1lık Üzerine Etkisi: Kıyı Ege Bölgesi'ndeki Bankacılık Sektörü Üzerine Bir Çalışma, TurkishStudies, International Periodical for the Languages, 10 (10), 249-266.

Ceylan, A. \& Ulutürk, Y. (2011). Rol belirsizliğgi, rol çatışması, iş tatmini ve performans arasındaki ilişkiler. Doğuş Üniversitesi Dergisi, 7(1), 48-58.

Çalışkan A., Akkoç, İ. \& Turunç Ö. (2011). Örgütsel performansın artırılmasında motivasyonel davranışların rolü: yenilikçilik ve girişimciliğin aracılık rolü, Süleyman Demirel Üniversitesi IIBF Dergisi, 16(3), 363-401.

Çarıkçı, İ. H. \& Oksay, A. (2004). Örgütsel yapı ve meslek farklılıklarının iş tatmini üzerindeki etkileri: hastane çalışanları üzerine bir araştırma. Demirel Üniversitesi Iktisadi ve Ídari Bilimler Fakültesi Dergisi, 9(2), 157172.

Çöl, G. (2008). Algılanan Güçlendirmenin İşgören Performans1 Üzerine Etkileri, Doğuş Üniversitesi Dergisi, 9(1), 35-46.

Dozier, D. M. (2005). Iletişim ve Halkla İlişkiler Uygulayıcılarının Örgütsel Rolleri. Rota Yayınları: İstanbul.

Eray, T. E. (2017). Rol çatışması, rol belirsizliği ve iş tatmini arasındaki ilişkiler: iletişim fakültesi dekanları üzerine bir uygulama. Akdeniz Iletişim Dergisi, 203213.

Fisher, R.T. (2001). Role stress, the type a behaviour pattern,

and external auditor job satisfaction and performance, Behavioral Research in Accounting, Vol.13 p.143.

Gökçe, O. \& Şahin, A. (2003). Yönetimde rol kavramı ve yönetsel roller. Sosyal ve Ekonomik Araştırmalar Dergisi,3(6), 133-156.

Griffen, R. W. (2008). Management. Boston: Houghtom Miffllin Company.

Helvacı, M.A. (2002). Performans yönetimi sürecinde performans değerlendirmenin önemi. Ankara Üniversitesi Eğitim Bilimleri Fakültesi Dergisi,35(1-2), 41-42.

House, R. J., Schuler, R. S. \& Levanoni, E. (1983). "Role Conflict and Ambiguity Scales: Reality or Artifacts?", Journal of Applied Psychology, 68(2), 334-337.

Judge, T. A., Woolf, E. F., \& Hurst, C. (2009), "Is Emotional Labor More Difficult For Some Than For Others? A Multilevel, Experience-Sampling Study", Personnel Psychology, 62(1), 57-88.

Katz, D. \& Kahn, R. L. (1977). Örgütlerin Toplumsal Psikolojisi, Çev. Halil Can ve Yavuz Bayar, Doğan Basımevi, Ankara.

Keller, R. T. (1975). Role Conflict and Ambiguity: Correlates with Job Satisfaction and Values, Personnel Psychology, 28, 57-64.

Kirkman, B. L. \& Rosen, B. (1999). Beyond SelfManagement: Antecedents and Consequences of Team Empowerment, Academy of Management Journal, 42:1, s. 58-74.

Özmutaf, N. M. (2007). Örgütlerde bireysel performans unsurları ve çatışma. Çukurova Üniversitesi İktisadi ve Ídari Bilimler Dergisi, 8(2), 41-60.

Rizzo, J.R., House, R.J. \& Lirtzman, S.I. (1970). Role Conflict and Ambiguity in Complex Organizations. Administrative Science Quarterly, 15(2), 150-163.

Schuler, R. S., Aldag, R. J. \& Brief, A. P. (1977). "Role Conflict and Ambiguity: A Scale Analysis". Organizational Behavior and Human Performance, 20: 111-128.

Sekaran, U. (1992). Research Methods For Business, Canada: John Wiley ve Sons, Inc.

Sigler, T. H. \& Pearson, C. M. (2000). Creating an empowering eulture: examining the relationship between organizational culture and perceptions of empowerment, Journal of Quality Management, 5, 2752.

Üner, M. M. (2008). Genel İşletmecilik. 1. Bask1, Detay Yayıncılık, Ankara. 